8-2002

\title{
Forensics and Case Studies in Civil Engineering Education: State of the Art
}

\author{
Norbert J. Delatte \\ Cleveland State University, n.delatte@csuohio.edu \\ Kevin L. Rens \\ University of Colorado at Denver
}

Follow this and additional works at: https://engagedscholarship.csuohio.edu/encee_facpub

Part of the Civil Engineering Commons, and the Engineering Education Commons

How does access to this work benefit you? Let us know!

\section{Publisher's Statement}

(c) ASCE

\section{Original Citation}

Delatte, N., and Rens, K. (2002). "Forensics and Case Studies in Civil Engineering Education: State of the Art." J.Perform.Constr.Facil., 16(3), 98-109.

This Article is brought to you for free and open access by the Civil and Environmental Engineering at EngagedScholarship@CSU. It has been accepted for inclusion in Civil and Environmental Engineering Faculty Publications by an authorized administrator of EngagedScholarship@CSU. For more information, please contact library.es@csuohio.edu. 


\title{
Forensics and Case Studies in Civil Engineering Education: State of the Art
}

\author{
Norbert J. Delatte, M.ASCE, ${ }^{1}$ and Kevin L. Rens, M.ASCE ${ }^{2}$
}

\begin{abstract}
This paper reviews the state of the art in the use of forensic engineering and failure case studies in civil engineering education. The study of engineering failures can offer students valuable insights into associated technical, ethical, and professional issues. Lessons learned from failures have substantially affected civil engineering practice. For the student, study of these cases can help place design and analysis procedures into historical context and reinforce the necessity of lifelong learning. Three approaches for bringing forensics and failure case studies into the civil engineering curriculum are discussed in this paper. These are stand-alone forensic engineering or failure case study courses, capstone design projects, and integration of case studies into the curriculum. Some of the cases have been developed and used in courses at the United States Military Academy and the Univ. of Alabama at Birmingham, as well as at other institutions. Finally, the writers have tried to assemble many of the known sources of material, including books, technical papers, and magazine articles, videos, Web sites, prepared PowerPoint presentations, and television programs.
\end{abstract}

CE Database keywords: Engineering education; Case reports; Forensic engineering.

\section{Introduction}

In response to several well-publicized engineering failures, the ASCE Technical Council on Forensic Engineering (TCFE) was established in 1982. The purpose of the TCFE is to

- Develop practices and procedures to reduce failures;

- Disseminate information on failures and their causes, providing guidelines for conducting failure investigations;

- Encourage research and education in forensic engineering; and

- Encourage ethical conduct in forensic engineering practice.

In addition to ASCE's board of direction's executive committee, the TCFE consists of six units:

- Forensic engineering practice;

- Dissemination of failure information;

- Technology implementation;

- Practice to reduce failures;

- Publication; and

- Education.

The TCFE's Committee on Education encourages universities to include forensic engineering and failure case studies in civil engineering education (Rendon-Herrero 1993a,b). The mission of

\footnotetext{
${ }^{1}$ Assistant Professor, Dept. of Civil and Environmental Engineering, 1075 13th St. South, Suite 120, Univ. of Alabama at Birmingham, Birmingham, AL 35294-4440.

${ }^{2}$ Associate Professor, Dept. of Civil Engineering, 1200 Larimer St., Univ. of Colorado at Denver, Denver, CO 80217-3364.
}

the Committee on Education is to develop resources to meet educational needs and to implement education programs. Although forensic engineering is a growing field, a void remains in forensic engineering education. This committee encourages the inclusion of forensic engineering topics and failure case studies in civil engineering education at the graduate and undergraduate levels, as well as continuing education programs. The committee also recommends activities to promote and advance the educational objectives of colleges and universities. Finally, the committee acts as a source of referral for educational material with a forensic engineering emphasis. It is this last point at which overlap exists with the TCFE's Dissemination of Failure Information Committee. In fact, if one looks at the deliverables of each TCFE committee, it could be argued that a large percentage of the council's activity is indeed geared toward education.

The study of engineering failures can offer students valuable insights into associated technical, ethical, and professional issues. Many writers have pointed out the need to integrate lessons learned from failure case studies in civil engineering education (Bosela 1993; Rendon-Herrero 1993a,b; Baer 1996; Delatte 1997; Rens and Knott 1997; Pietroforte 1998; Carper 2000; Delatte 2000; Jennings and Mackinnon 2000; Rens et al. 2000d).

The editor of ASCE's Journal of Performance of Constructed Facilities addressed this need in an editor's note in the February 1998 issue. Some educators have developed upper-level courses in failure analysis and forensic engineering as electives or graduate offerings, but few civil engineering undergraduates are able to take advantage of them. It is not practical to add another mandatory course to already crowded civil engineering undergraduate curricula. In some cases, failure investigations have been used as problems for capstone design courses. Another approach is to integrate case studies into existing courses.

This paper reviews the state of the art for using forensics and failure case studies in civil engineering education and discusses 
all three of the approaches introduced above.

Many of the key technical principles that civil engineering students should learn can be illustrated through case studies. For example, the first writer has discussed the Hyatt Regency walkway collapse in Kansas City, Missouri, the Tacoma Narrows Bridge failure in Washington, and other well-known cases with students in statics, mechanics of materials, and other courses. As another example, the second writer has discussed temporary steel bracing failures on masonry walls and temporary timber bracing on wood trusses in steel design and capstone design courses (Rens et al. 2000e). These cases help students to

- Grasp difficult technical concepts and begin to acquire an "intuitive feel" for the behavior of structures and the importance of load paths and construction sequences;

- Understand how engineering science changes over time as structural performance is observed and lessons are learned;

- Analyze the impacts of engineering decisions on society; and

- Appreciate the importance of ethical considerations in the engineering decision-making process.

In a survey conducted by the ASCE TCFE's education committee in December 1989, reported by Rendon-Herrero (1993a, b) and Bosela (1993), about a third of the 87 civil engineering schools responding indicated a need for detailed, welldocumented case studies. The response from the Univ. of Arizona said "ASCE should provide such materials for educational purposes," and the response from Swarthmore College suggested "ASCE should provide funds for creating monographs on failures that have occurred in the past" (Rendon-Herrero 1993b).

The ASCE TCFE conducted a second survey in 1998 that was sent to all Accreditation Board for Engineering and Technology (ABET)-accredited engineering schools throughout the United States (Rens et al. 2000d). As with the 1989 survey, the lack of instructional materials was cited as a reason that failure analysis topics were not being taught. One of the unprompted written comments in that survey was "A selected bibliography is needed on the topic, which could be accessed via the Internet." Another comment went on to say "The best things TCFE can do are (1) provide instructional materials to make it easy for a teacher to incorporate failures in their courses, and (2) provide Internet materials so instructors can give self-guided homework assignments." Still another responder to the 1998 survey indicated "Need published case studies such as project designs, failures, evaluations, etc."

This paper provides some resources, but this is by no means a complete bibliography. A fairly comprehensive bibliography of references available through 1996 was published by Nicastro (1996). Puri (1998) and Carper (2000) list several additional references that could be used as well. The combination of the references in these three papers with the references in this state-of-theart paper provides a fair representation of the published failure analysis work to date.

\section{Forensic Engineering and Failure Case Study Courses}

Several papers have been written describing courses on forensic engineering or failure case studies at various universities (Bosela 1993; Rens and Knott 1997; Pietroforte 1998). In the previously mentioned 1989 TCFE survey (Bosela 1993; Rendon-Herrero 1993), 8 of the 87 university respondents offered a course on failures of structures. Although not specifically asked for in the 1998 TCFE survey, 5 of the 112 university respondents specifically mentioned a stand-alone failure analysis course. One com- ment indicated, "We have two MS level courses (in which undergraduates can enroll) that are dedicated to failure analysis and performances in structural and geotechnical engineering." Another comment went on to say, "The department offers a graduate level course on infrastructure surety, which is devoted almost entirely to what may go wrong in construction situations." And finally, one institution indicated, "We will introduce a new elective undergraduate course on forensic engineering and failure investigations next spring." The two TCFE surveys indeed illustrate that stand-alone failure courses are rare.

Some universities offer forensic engineering courses as electives, although these courses mainly appear at the graduate level (Carper 2000). Forensic engineering courses typically have the educational objective of teaching students to become forensic engineers. Since forensic engineering is generally practiced by expert engineers, these courses are usually only available to graduate students and upper-division undergraduates. Furthermore, these types of courses may require faculty who are practicing forensic engineers. Baer (1996) pointed out that faculty with the necessary background to teach these types of course are rare.

These courses have been taught by Fowler at the Univ. of Texas (UT, taken by the first writer in 1994), Rens and Knott at the Univ. of Colorado, Denver (UCD) (Rens and Knott 1997), and Rendon-Herrero at Mississippi State Univ. (MSU). Table 1 shows some topics typically addressed in forensic engineering course syllabi at these three universities.

There are similarities and differences. All three courses rely heavily on case studies, written and oral student projects, and presentations. The UCD course combines forensic engineering for civil and mechanical engineers with nondestructive evaluation (NDE) methods. NDE is a tool used in many failure analysis investigations that allows students hands-on laboratory training with relatively inexpensive equipment. In the NDE portions of the courses, students are required to use standard samples in addition to making their own case studies.

In one example, students acquired flawed steel that contained the rolling/milling flaw of lamellar tearing. The student team was able to prove that the steel contained these flaws by using highfrequency ultrasound, nondestructive testing equipment. In another example, students illustrated how voids in large-grained building materials such as concrete and masonry can be detected by low-frequency ultrasound. Still other examples illustrated how dye penetrant and magnetic particle testing can be used to highlight cracks and flaws in metals that are not visible to the naked eye. Students are required to produce a professional report and to defend it orally.

Although the course is cotaught with a practicing failure analysis engineer (Dr. Albert Knott), it does involve guest speakers such as NDE engineers, other practicing forensic engineers, attorneys, and technicians. All of the assigned student projects for the UCD course are taken from actual case studies led by Knott. Because actual case studies are used, the reports are first sanitized to remove any ties to the engineers, clients, and other associated parties. Students are given photographs, actual field notes, actual police evidence, videotapes, and other information about expired projects. In some cases, students are allowed to interview the actual assigned engineer. As in the NDE portion of the course, student-written presentations and oral defenses are required.

The UT course concentrates on civil engineering, with emphasis on structural evaluations. The UT and MSU courses rely heavily on guest speakers, including an attorney, a petrographer, and a retired judge. 
Table 1. Typical Forensic Engineering Course Syllabus

Topic $\quad$ Hours

(a) CE 5806, Forensic analysis and condition assessment of civil and mechanical infrastructure-Univ. of Colorado, Denver (Rens and Knott 1997)

$\begin{array}{ll}\text { Infrastructure inspections } & 1.5 \\ \text { Failures due to expansive soils } & 3.0 \\ \text { Nondestructive evaluation (NDE)_dye penetrant, } & 12.0 \\ \text { ultrasound, magnetic particle methods } & \\ \text { Hyatt Regency and other cases } & 1.5 \\ \text { Vehicular accident reconstruction } & 4.5 \\ \text { Ethical issues in vehicular accident reconstruction } & 1.5 \\ \text { Product failure investigation } & 1.5 \\ \text { NDE of timber structures } & 1.5 \\ \text { NDE of steel structures } & 1.5 \\ \text { NDE of masonry structures } & 1.5 \\ \text { NDE of concrete structures } & 1.5 \\ \text { Depositions and court testimony } & 3.0 \\ \text { Construction and product law } & 3.0 \\ \text { Ethics in engineering practice } & 1.5\end{array}$

(b) ARE 383/CE 397 Forensic engineering-Univ. of Texas Introduction - what is forensic engineering? Qualifications, role, history of failure, failure statistics Causes of failures - definition, classification, causes, specific causes

Investigation - planning, client interface/schedule/ budget, team, site observations/testing/analysis, document search, historical information/visual documentation, literature search, synthesis, development of conclusions

Case studies - residential structure, concrete structure, concrete materials, masonry walls, building envelope Engineer in dispute resolution - civil litigation process, pretrial responsibilities, trial responsibilities, alternate dispute resolution

Issues in forensic engineering - ethics, professionalism, liability

(c) CE 4003 Forensic engineering-Mississippi State Univ. Introduction, definitions, and discussion of legal 4.5 process

Failure case studies and causes $\quad 1.5$

Natural hazards and unusual loads $\quad 1.5$

Engineer as expert witness $\quad 4.5$

Learning from failures $\quad 3.0$

Investigation $\quad 6.0$

Fire, industrial, product liability $\quad 4.5$

Traffic accident and transportation $\quad 3.0$

Environmental systems failures $\quad 1.5$

Case studies

4.5

As with the UCD course, an important feature of the UT course is that each student must independently carry out a building investigation, write a report, and present the results. Campus buildings are used in order to avoid issues of liability and confidentiality. The university also benefits from free consulting services, although the staff is advised to consider the reports carefully before taking any action.

The MSU course has evolved considerably over the years, and the topics shown in Table 1 reflect the Fall 2001 course offering.
A review of course syllabi from fall 1991 onward shows that the broad themes addressed have remained the same, with topics such as dispute resolution techniques, construction safety, nonstructural failures, and dams and bridges being occasionally covered. Three to five guest lecturers are used, and some offerings include in-class mock trials or debates.

Pietroforte (1998) described a failure case study course recently developed at Worcester Polytechnic Institute (WPI) in Massachusetts. This course was developed in conjunction with a new Master Builder program - a five-year program leading to the award of a combined BSCE and MSCE degree. The course title is "Construction Failures: Analysis and Lessons." Five case studies are presented and discussed in detail in class, and students write term projects on cases from the literature and present the results. In contrast to the courses at UCD and UT, the WPI course focuses on failures and lessons learned, rather than the practice of forensic engineering. However, it should be noted that lessons learned from failures are an implied intrinsic by-product of the discussion of a failed engineering project - especially in an educational setting.

Both Pietroforte and the first writer (Delatte) took a course at the Massachusetts Institute of Technology (MIT) in fall 1984, taught by Irwig and Becker, that incorporated two Boston failure case studies-Hotel Vendome and 2000 Commonwealth Avenue. This MIT course provided a useful stimulus toward the inclusion of case studies in engineering education. The first writer has taught a course at the Univ. of Alabama at Birmingham (UAB), "Engineering the Environment," that introduced a number of basic civil engineering concepts through failure case studies and other historical examples.

At this point it is useful to consider separately courses that teach forensic engineering and courses that teach engineering practice through failure case studies because these different categories of courses have different objectives. The courses in the former category (e.g., UCD, UT, and MSU) are intended to introduce graduate students with sound technical backgrounds to investigate methods, depositions, testimony, and other details of forensic engineering practice such as writing and speaking, although some time is spent on technical topics. A proper definition of forensic engineering, after all, is that it is engineering practiced in a public forum, such as within the legal system.

In the second category, courses on failure case studies can be of considerable value. In addition to technical material, valuable lessons in engineering practice, ethics, and professionalism can be taught. Another option is to use such a course to teach research and technical communication skills. However, it should be noted that no matter which type of failure analysis course one is considering, each should incorporate lectures involving case studies as these examples essentially make up the textbook.

Outside the United States, students participating in a "learning from disasters" exercise at Queen's Univ., Belfast, investigated a number of failures and disasters. The exercise was carried out in the first two years of the bachelor's and master's degree curricula. These researchers (Jennings and Mackinnon 2000) noted, "It has become clear how little students generally know about key disasters which are common knowledge to their elders and which have had a profound effect on the profession." The same can be said of the majority of U.S. students as well. Even though well-published cases such as the Hyatt Regency walkway collapse, Willow Island cooling tower, (West Virginia), or Hartford Civil Center (Connecticut) failure are common knowledge to moderately seasoned engineers, they tend to be new issues to 20 -year-old engineering students. 


\section{Design Capstone Courses and Forensic Engineering}

Under the urging of ABET, many universities have developed a capstone or senior design course that gives students actual engineering problems to solve. These courses are becoming increasingly important in many engineering programs (Dutson et al. 1997). Students often work in teams on projects gathered from the surrounding community. Among the problems to solve may be failures or rehabilitation of existing facilities. One respondent to the 1998 TCFE survey did indicate that failure analysis topics were introduced in the design capstone courses.

An excellent example of how to incorporate failure analysis in the capstone design course can be found at MSU, where Professor Oswald Rendon-Herrero has been incorporating failure analysis topics into the civil engineering curriculum since 1973. A recent paper discusses how a term project in the foundation design capstone course involves failure analysis (Rendon-Herrero 1998). This course is offered on an annual basis each spring and regularly has an enrollment of around 30 students.

As a background to the course, it should be noted that the MSU region is known for its highly expansive soils, which are native to the area. Many homes suffer from distresses that range from either minor cosmetic problems to general foundation problems. The cosmetic problems range from dry wall cracking, inoperable doors and windows, elevation problems, or other functional types of distresses, while the general foundation problems can involve heaved piers or foundations, concrete cracking, or other safety issues. Before the semester begins, Rendon-Herrero has a meeting with the local newspaper and runs a short story about the upcoming semester term project. The article is designed to solicit owners of homes containing functional or structural safety distresses to submit an application to be a case study for the semester-long course. MSU is located in the town of Starksville, Miss., which has a population of around 35,000 people. According to Rendon-Herrero, in a typical semester, around 35 homeowners respond to the solicitation.

At the beginning of the semester, each of the homeowners is interviewed by the students and each residence is ranked based on a variety of parameters such as magnitude of problem, availability of and access to the home, availability of design information (that is, design plans or specifications), age of home, and friendliness of the homeowner. After the initial interview process, the top 10 or so homes are chosen based on a three-student-per-house ratio.

The term project involves six or seven tasks with milestone benchmarks at certain intervals during the semester. As an example, the first benchmark, set a short period after the semester begins, involves a second detailed interview of the homeowner, a detailed inspection of the residence involving visual inspections and photography, and a literature review of the published USDA soil survey report. At each benchmark, Rendon-Herrero reviews reports and offers advice to the student teams. Another benchmark involves obtaining actual soil borings with a hand auger to produce a core in order to develop boring logs. Other soil laboratory tests are performed and are compared to the published USDA soil report, usually with a favorable correlation.

Three weeks before the semester is over, students are required to put the entire puzzle together and come up with a theory of the residence behavior, source of problems (usually drainage or other water source or faulty construction), and a tentative rehabilitation scheme. Each student team defends a written and oral report. The final deliverable is a wrap-up inspection report that is given to the owner. Rendon-Herrero then offers his own failure theory and rehabilitation advice to the owner in the form of a marked-up student report with a typical disclaimer.

Although the term project is a tremendous amount of work, given that normal foundation lectures and homework such as footing and retaining wall analysis and design are also required, Rendon-Herrero is anxious each spring to continue the tradition.

A similar project at North Dakota State Univ., describing forensic analysis of slope stability problems around a lake, is discussed in a paper by Padmanabhan and Katti (2002). Eleven groups of six students each investigated the problem and proposed mitigation solutions. Although a failure analysis project was discussed in the paper, most capstone projects at that university do not involve failures or forensic engineering.

\section{Integration Into Curriculum}

The 1998 TCFE survey revealed that perhaps the best way to introduce undergraduates to failure analysis and lessons learned from failures was to allow case studies to permeate undergraduate courses. Nearly all the respondents felt that a few lectures were sufficient to reinforce basic engineering concepts. Few respondents indicated the need for four or more lectures. Several unprompted written comments were received, each with a theme similar to the following comment: "(design) courses should include failure information as a part of lecture and laboratory efforts. This information should be provided at the undergraduate level on an ongoing basis as opposed to stand-alone courses." The respondent went on to say that "Stand-alone courses should be reserved for the Master's degree level courses." This final statement echoes many comments provided.

Therefore, one solution is to integrate case studies and lessons learned into existing courses. The main obstacle to this is that many faculty do not have time to research and prepare case studies. The review below builds on previous work (Delatte 2000) to suggest some courses, lesson topics, and cases. Available sources of well-developed case studies and teaching materials are also identified.

\section{Use of Case Studies}

The first writer has used case studies such as these at the United States Military Academy (USMA) and at the UAB in such courses as statics, mechanics of solids, and reinforced concrete. Some of the ways to integrate failure case studies and a suggested format were reviewed in Delatte $(1997,2000)$. These include

- Introductions to topics: Use the case to illustrate why a particular failure method is important. Often the importance of a particular mode of failure only became widely known after a failure; examples include the wind-induced oscillations of the Tacoma Narrows Bridge and the Air Force warehouses (Ohio and Georgia) without reinforcement for shear and dimensional changes, discussed below;

- Class discussions: Link technical issues to ethical and professional considerations;

- Example problems: Calculate the forces acting on structural members and compare them to design criteria and accepted practice; and

- Group and individual projects: Have students research the cases in depth and report back on them. This will also help build a database of cases for use in future classes.

In the writers' opinion the best way to incorporate cases into classroom discussions is to link them to specific topics, as sug- 
Table 2. Courses, Topics, and Case Studies (based on Delatte 2000)

\begin{tabular}{|c|c|c|}
\hline Course & Topic & Case study \\
\hline Statics & Free-body diagram & $\begin{array}{l}\text { Hyatt Regency walkway collapse } \\
\text { T. W. Love Dam cantilever form failure }\end{array}$ \\
\hline Dynamics & Mass moment of inertia and stiffness & Tacoma Narrows Bridge collapse \\
\hline \multirow[t]{3}{*}{ Mechanics of materials (solids) } & $\begin{array}{l}\text { Kinetics: dynamic forces } \\
\text { Stress and strain }\end{array}$ & $\begin{array}{l}\text { Bomber crash into Empire State Building } \\
\text { Shrinkage of concrete masonry units } \\
\text { and swelling of brick masonary }\end{array}$ \\
\hline & $\begin{array}{l}\text { Structural deformation as warning } \\
\text { of impending collapse }\end{array}$ & Hartford Civic Center \\
\hline & Elastic buckling & Stepped roof structure, Elwood, N.Y. \\
\hline \multirow[t]{5}{*}{ Structural analysis } & Loads on structures & Bomber crash into Empire State Building \\
\hline & Load paths & L'Ambiance Plaza collapse \\
\hline & Structural deformation & Quebec Bridge \\
\hline & & Hartford Civic Center \\
\hline & Checking computer results & Hartford Civic Center \\
\hline \multirow[t]{6}{*}{ Reinforced concrete design } & Structural integrity of formwork & New York Coliseum \\
\hline & Strength development of concrete & Willow Island cooling tower \\
\hline & & 2000 Commonwealth Avenue, Boston \\
\hline & & Bailey’s Crossroads, Virginia \\
\hline & Punching shear in concrete slabs & Harbor Cay condominium, Florida \\
\hline & Reinforcement development length & Pittsburgh Midfield Terminal precast beam collapse \\
\hline \multirow[t]{3}{*}{ Steel design } & Connections & Hyatt Regency walkway collapse \\
\hline & & Steel frame connections in Northridge earthquake \\
\hline & Buckling & $\begin{array}{l}\text { Stepped roof structure, Elwood, N.Y. } \\
\text { Ouebec Bridge }\end{array}$ \\
\hline Introduction to engineering or capstone & Professional ethics & Citicorp Tower \\
\hline
\end{tabular}

gested in this section. Student response to the cases developed so far has been enthusiastic. The most successful case studies are those that inspire students to go out, do their own research, and learn more about their chosen profession.

\section{Courses and Lesson Topics}

Lesson topics should be identified for required courses in a civil engineering curriculum. Once these have been identified, it is possible to suggest case studies to support the topics. Some courses, topics, and case studies are suggested in Table 2.

\section{Engineering Mechanics}

For the purposes of this discussion, engineering mechanics refers to courses in statics, dynamics, and mechanics of materials (also called strength of materials or mechanics of solids). At some schools, such as USMA or UAB, the civil engineering faculty often teach these courses and can easily incorporate appropriate case studies. Where these courses are taught by other departments, it may be necessary to address these topics in a later course, such as structural analysis. An earlier paper discussed seven case studies developed for engineering mechanics courses (Delatte 1997). A discussion by Puri (1998) provided comments as well as additional exercises and examples.

The free body diagram is the basic equilibrium analysis tool used to determine forces acting on a body. If the diagram is not drawn correctly, the forces cannot be calculated accurately and the design may be unsafe. The importance of a correct free body diagram may be shown through analysis of the Kansas City Hyatt Regency walkway collapse. A free body diagram of the original detail, on the left in Fig. 1, shows that the nut-to-beam connection supports the weight of a single deck, or $P$. In contrast, the free body diagram of the as-built detail now requires the nut-to-beam connection to transfer $2 P$. The load on the connection was doubled, and it failed. An excellent discussion of this case, with emphasis on ethical issues, is provided by Roddis (1993).

This case was revisited, with considerable new information and analysis, in four papers published in a special issue of ASCE's Journal of Performance of Constructed Facilities (Gillum 2000; Luth 2000; Moncarz and Taylor 2000; Pfatteicher 2000). In addition, all four writers published and presented abbreviated versions of ASCE's 2nd forensic congress (Rens et al. 2000c).

\section{Structural Analysis}

At institutions where engineering mechanics courses are taught outside the civil engineering department, it may be desirable to address some of the cases in engineering mechanics in later courses. Case studies appropriate for inclusion in a structural analysis course are discussed as follows.

\section{Loads Acting on Structures}

Accurate prediction of loads acting on structures is difficult, but extremely important. This topic is addressed in Chapter 2 of Feld and Carper (1997). The bomber crash into the Empire State Building (New York) (Delatte 1997) as well as the Oklahoma City Federal Building (Oklahoma) bomb are examples of extraordinary loads acting on buildings. In addition, introduction of basic wind, snow, or other live loads tends to be a topic overlooked in many engineering courses - that is, usually the loads are a given parameter. It is important for instructors to discuss the nature and variability of both ordinary and extreme loads in lectures. 

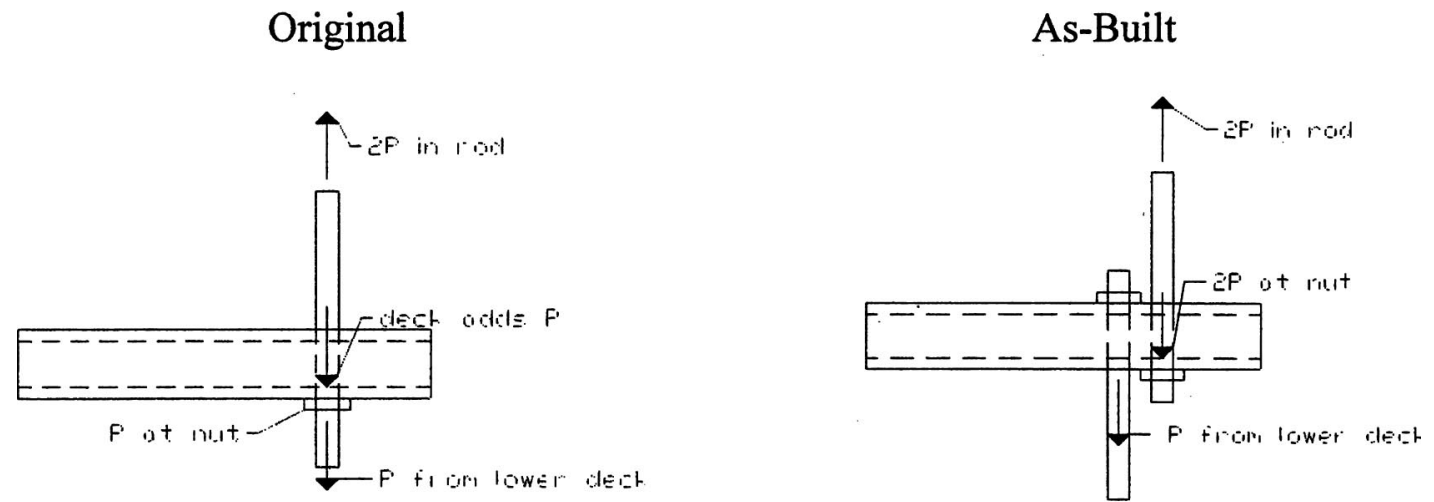

Fig. 1. Original and as-built hanger details

\section{Load Paths}

It is important that the designer provide a continuous load path at all times to transfer all loads safely to the foundation. There are many competing theories as to why the L'Ambiance Plaza (Connecticut) towers collapsed while under construction, but each theory is based on a break in the load path. The state of construction just before collapse is illustrated in Fig. 2, which shows an elevation of the building with the packages of slabs being jacked up together. Six theories are discussed in Martin and Delatte (2000). Several of the theories focus on the lift heads (Fig. 3) used to lift the slabs in position.

\section{Calculating Structural Deformations}

Accurate calculation of structural deformation is important for two reasons. The first is that excessive deformations may lead to serviceability problems, causing nonstructural damage or making continued use of the facility difficult or impossible. This is why codes limit these deformations. The second is that if deformations during construction or while the building is in service greatly exceed predictions, this is a warning that the structure may be in danger of collapse.

In two cases, higher-than-expected deformations were ignored until it was too late. Before the Quebec River Bridge (Canada) collapsed in 1907, killing 82 workers, compression members were observed to be distorted by up to $57 \mathrm{~mm}\left(2 \frac{1}{4} \mathrm{in}\right.$.), indicating incipient buckling. An excellent account of this tragedy is provided by Roddis (1993). The collapse of the Hartford Civic Center in 1978 also occurred after excessive structural deformations observed during construction had been ignored. Bracing for the compression members of the roof space truss (Fig. 4) proved to be inadequate, and several members failed by buckling. This case is reviewed in detail in Martin and Delatte (2001).

\section{Checking Computer Results}

Petroski (1985) suggests that design of the Hartford Civic Center roof would never have been attempted without computers because the space truss would be very difficult to analyze by hand methods. He also suggests that uncritical acceptance of the computer solution played an important role in the catastrophe. Computer results can never substitute for understanding structural behavior. Several errors in application of finite-element analysis have been discussed (Bell and Liepins 1997). The engineer should know the approximate answer before sitting down in front of the computer and must be able to distinguish an accurate solution from one that is absurd but appears precise.

An excellent example of known failures as a result of computer misuse can be found in Puri (1997), where a 50-page paper was presented by the panel at ASCE's 1st forensic congress (Rens 1997). This report outlines 52 cases on computer misuse, failure types, error sources, and lessons learned.

\section{Reinforced Concrete Design and Concrete Materials}

A large number of case studies relate to concrete design and construction. Chapters 7 and 8 of Feld and Carper (1997) address this topic. Topics such as formwork, shoring, and other temporary structures are covered in the section titled "Structural Integrity during Construction."

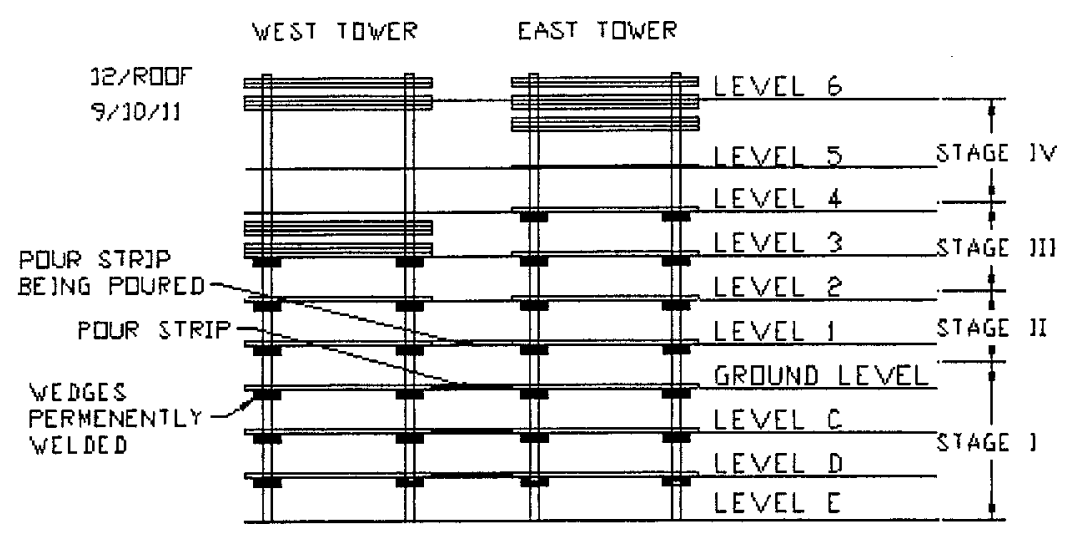

Fig. 2. L'Ambiance Plaza construction status just before collapse 


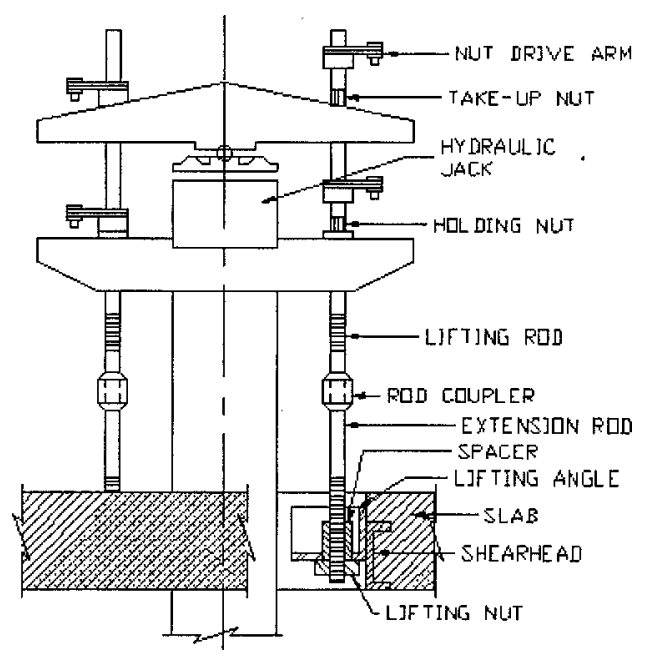

Fig. 3. L'Ambiance Plaza lift heads

\section{Strength Development of Concrete}

Twenty-eight day cylinder strength tells one how strong a concrete cylinder cured in a laboratory is at 28 days, but doesn't necessarily tell you much about the strength of the as-built structure. The strength gain of concrete is highly dependent on ambient temperature. In cold weather, the concrete in a structure will be much weaker at an early age than laboratory cylinder strengths cured at a different temperature.

The Willow Island, West Virginia, cooling tower collapsed while under construction on April 27, 1978, killing 51 workers in the worst construction disaster in U.S. history (Lew et al. 1979; Ross 1984; Kaminetzky 1991; Feld and Carper 1997; LaCome et al. 2000). A jump-form system was being used, with the forms secured by bolts in one-day and three-day-old concrete; the forms were designed to be progressively moved up the tower as it was built. The temperature had been in the mid-thirties at night. The National Bureau of Standards found that the concrete had not attained enough strength to support the forms. The report concluded that "the most probable cause of the collapse was the imposition of construction loads on the shell before the concrete of lift 28 had gained adequate strength to support these loads"
(Lew et al. 1979). LaCome et al. (2000) further show how the concrete maturity method can be used with the actual published information to determine the strength of the concrete at failure.

An investigation into the collapse of a 17-story concrete highrise under construction at 2000 Commonwealth Avenue, Boston, disclosed a number of irregularities and deficiencies (Kaminetzky 1991), including the following, among others:

1. Lack of proper building permit;

2. Insufficient concrete strength;

3. Insufficient length of rebars;

4. Lack of proper field inspection;

5. Various structural design deficiencies;

6. Improper formwork;

7. Premature removal of formwork;

8. Inadequate placement of rebars; and

9. Lack of construction control.

Four workers were killed and 20 injured. Fortunately, the collapse occurred slowly enough for many of the workers to escape. The collapse occurred on January 25, and low temperatures had certainly retarded strength gain. Cores showed concrete compressive strengths as low as $4.83 \mathrm{MPa}$ (700 psi) (Kaminetzky 1991; Feld and Carper 1997).

Yet another formwork collapse blamed on inadequately cured concrete occurred at Bailey's Crossroads, Virginia, in March 1973. Fourteen workers were killed and 30 were injured. Shores were removed between the 22nd and 23rd floors of the building while concrete was being placed on the $24 \mathrm{th}$. The collapse tore an $18 \mathrm{~m}$ (60-ft) wide gap through the building all the way to the ground. The concrete, when tested, turned out to be well below its expected strength. The floor slab failed in punching shear at the columns (Ross 1984; Kaminetzky 1991; Feld and Carper 1997).

Dimensional Changes in Concrete and Shear Reinforcement Two warehouse roofs at U.S. Air Force bases in Ohio and Georgia cracked and collapse under combined load, shrinkage, and thermal effects in 1955 and 1956. Continuous $122 \mathrm{~m}$ (400 ft) lengths of reinforced concrete roof girders functioned as single units because of defective expansion joints. Other warehouses, built to the same plans, survived because separation was maintained between adjacent $61 \mathrm{~m}(200 \mathrm{ft})$ bays. These failures led to more stringent shear steel requirements in subsequent editions of the ACI Build-

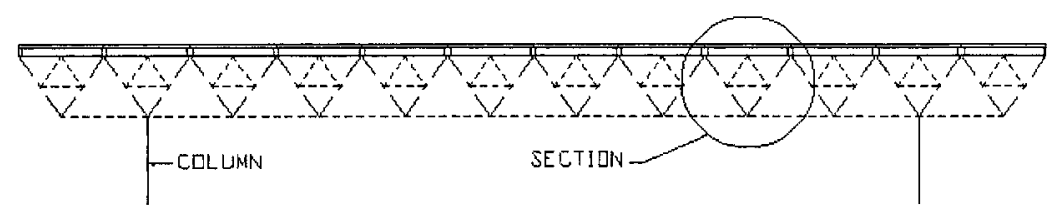

Space Frame Roof

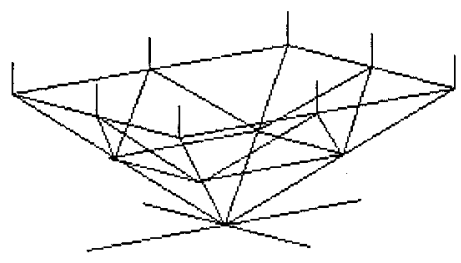

Section of the Space Frame Roof

Fig. 4. Hartford Civic Center roof 
ing Code. In these structures, the concrete alone, with no stirrups, was expected to carry the shear forces, and the members had no shear capacity once they cracked (McKaig 1962; Feld and Carper 1997).

\section{Reinforcing Steel Placement and Punching Shear}

Numerous design errors were uncovered when the five-story Harbor Cay Condominium, Cocoa Beach, Florida, collapsed under construction in 1981, killing 11 workers and injuring 23. Incredibly, no punching shear calculation had been made for the concrete floor slabs. Furthermore, the slabs were only $200 \mathrm{~mm}$ (8 in.) thick and should have been $280 \mathrm{~mm}$ (11 in.) thick to satisfy the ACI Building Code minimum. The chairs used to support the slab steel were $108 \mathrm{~mm}$ ( $4 \frac{1}{4}$ in.) high, which, coupled with the thin slabs, led to a very small effective depth (Lew et al. 1982; Kaminetzky 1991).

\section{Development Length of Reinforcing Steel}

Unless a sufficient development length of steel is embedded in concrete, the bar will pull out before it yields. In 1990 a portion of the Pittsburgh Midfield Terminal (Pennsylvania) failed during construction. In a precast concrete beam the bottom reinforcing bar was embedded only $185 \mathrm{~mm}$ ( $7 \frac{1}{4}$ in.), which is much shorter than necessary (Thornton and DeScenza 1997).

\section{Structural Steel Design}

A number of case studies involving steel structures are reviewed in Chapter 6 of Feld and Carper (1997). Others are discussed in Kaminetzky (1991). Critical issues for steel structures are connection detailing and buckling. The cases of the Hyatt Regency for connections and the Hartford Civic Center for buckling can be used if they have not been addressed earlier in the curriculum.

\section{Connection Details}

Many cases in structural engineering have illustrated the importance of careful attention to connections. The Northridge Earthquake of 1994 showed that the special moment-resisting frame welded connection behaved much worse than anticipated during the event [four papers in Rens (1997), pp. 219-257]. This is an excellent example of the dangers of extrapolating behavior from small test specimens to full-scale structures and of why codes and standards continue to evolve.

\section{Soil Mechanics and Foundation Engineering}

Courses in soil mechanics and foundation engineering often discuss the Leaning Tower of Pisa, but many other case studies are available. Chapter 3 of Feld and Carper (1997) addresses earthwork, soil, and foundation problems, and Shepherd and Frost (1995) list foundation and geoenvironmental case studies. Papers published in ASCE's Journal of Performance of Constructed Facilities address several topics:

- Problem fill materials, soil shrinkage, and expansive soils (Gnaedinger et al. 1987; Richardson et al. 1987; Raghu and Hsieh 1989; Day 1992, 1994a, b, 1995; Meehan and Karp 1994).

- Lateral earth pressure and retaining walls (Lin and Hadipriono 1990; Day 1993; Diaz et al. 1994; Leonards et al. 1994).

- Soil bearing capacity (Whitlock and Mossa 1996; Amini and Khalilian 1997).

Two books (Handy 1995; Shallow 1995) provide a thorough but understandable discussion of engineering geology and soil mechanics and their influence on the performance of facilities.

\section{Structural Integrity during Construction}

Although a specific course is not available that teaches all the basics of temporary design construction issues such as formwork, shoring, masonry wall bracing, and timber truss bracing, it is a topic that can permeate other design courses, such as concrete design, timber design, steel design, and foundation design. Perhaps the best course to address this topic would be a capstone senior design course. Chapter 11 of Feld and Carper (1997) is specifically dedicated to bracing issues and failures.

\section{Temporary Bracing}

As temporary bracing is usually a construction-sequencing event, many times the bracing and construction process is left for the field crew to decide. According to Feld and Carper (1997), in the United States alone, an average of 2,200 fatalities occur yearly in the construction industry. The economic loss is also staggeringaround $\$ 9$ billion lost annually to accidents. According to Kaminetzky (1991), in steel construction alone insufficient bracing accounts for $25 \%$ of the failures during construction. Temporary bracing is also a common failure issue in concrete construction. It is common for contractors to remove shoring and formwork as quickly as possible. Again, sequencing is always an issue as pressure is always mounting to move on to the next phase of construction in order to meet certain milestone deadlines. Improperly braced timber trusses and masonry walls are also common failure events. The second writer has been involved in several related case studies (Rens et al. 2000 e).

But who is responsible? Contractors in charge of construction routinely have the attitude, "if we work fast enough, we won't have to brace it, and nothing is likely to happen" (Feld and Carper 1997). However, it is generally the contractor's responsibility to provide the necessary bracing and make decisions about the most efficient construction sequence (Goldstein 1999). By common practice and custom, engineers provide designs for completed structures, including permanent bracing but not temporary bracing.

In any event, engineering education can make temporary bracing and construction sequencing a topic in capstone and structural design courses. The second writer has presented a paper involving two case studies of bracing failures and has suggested ways that simple application of related examples could integrate design and construction (Rens et al. 2000e). For example, the first case study involved an inadequately braced $6.1 \mathrm{~m}(20 \mathrm{ft})$ tall masonry wall. A typical windy Colorado evening caused a midsized commercial building to collapse. The case incorporated the determination of wind loads, also an often-overlooked civil engineering topic, and possible failure modes, including bracing buckling (steel design); connection design (steel design); punching failure (concrete/ masonry design); and soil anchorage failure (foundation design). The second case also involved wind interacting with the construction of a large school gymnasium. Again, a typical wind event caused 11-24.4 m (36-80 ft) long timber trusses to collapse. To make matters worse, the failure occurred twice during the setting of the trusses, each occurring over the weekend-no lessons were apparently learned. This case also involved the determination of wind loading and forces on connections (timber design).

\section{Structural Integrity of Formwork}

There is an economic incentive for a builder to keep formwork as inexpensive as possible and to remove it as quickly as possible so that it can be reused. Formwork is a structure, and like any structure can only stand if it is stable and load paths are maintained. 
Table 3. Available Case Study and Disaster Videotapes

\begin{tabular}{|c|c|}
\hline Title & Description and source \\
\hline $\begin{array}{l}\text { "To Engineer is Human: The Role of Failure in Successful } \\
\text { Design"" }\end{array}$ & $\begin{array}{l}\text { 1997, written and presented by Henry Petroski, producer Alec } \\
\text { Nesbitt, } 51 \text { min, published by Princeton, JH: Films for the } \\
\text { Humanities and Sciences: FFH 7378, distributed under license } \\
\text { from BBC Worldwide Americas, Inc., also available through } \\
\text { Films Incorporated Education, } 5547 \text { N. Ravenswood, Chicago, } \\
\text { IL 60640-1199 }\end{array}$ \\
\hline "The Day the Earth Shook" & $\begin{array}{l}\text { 1996, NOVA, written and produced by Simon Campbell-Jones } \\
\text { and Suzanne Campbell-Jones, Executive producer Paula S. } \\
\text { Apsell, } 60 \text { min, WGBH Educational Foundation } \\
\text { 〈www.wghb.org }\end{array}$ \\
\hline "Earthquake" & $\begin{array}{l}\text { 1990, NOVA, written and produced by Carl Charlson, Executive } \\
\text { producer Paula Apsell, } 60 \text { min, WGBH Educational Foundation } \\
\text { 〈www.wgbh.org }\end{array}$ \\
\hline "Earthquakes: The Terrifying Truth" & $\begin{array}{l}\text { 1994, written and produced by Alex Gregory, executive } \\
\text { producer, Dennis B. Kane, ABC Video Publishing, } 50 \text { min }\end{array}$ \\
\hline "Chernobyl Nuclear Disaster" & $\begin{array}{l}\text { 1990, MPI home video presentation of an } \mathrm{ABC} \text { news production, } \\
30 \mathrm{~min}\end{array}$ \\
\hline "Disaster Proof-Architectural Failures" & $\begin{array}{l}\text { 1996, written and produced by John Borst, SCI-TREK-The } \\
\text { Discovery Channel, } 30 \text { min 〈www.discovery.com〉 }\end{array}$ \\
\hline "The New Detective - Case Studies in Forensic Science" & $\begin{array}{l}\text { 1997, produced by Tom Naughton and Nicolas Valcon, written } \\
\text { by Stephen Zorn, } 30 \text { min, SCI-TREK-The Discovery Channel } \\
\text { 〈www.discovery.com〉 }\end{array}$ \\
\hline "Fatal Flaw_A Skyscraper's Nightmare" & $\begin{array}{l}\text { 1996, A\&E Investigative Reports, executive producer Andrea } \\
\text { Miller, directed by Roger Parsons, Kurtis Production Inc. } \\
\text { 〈www.aande.com 〉-also discussed in Morganstern (1997) }\end{array}$ \\
\hline "Academic Integrity: The Bridge to Professional Ethics" & $\begin{array}{l}\text { 1995, Center for Applied Ethics, Duke Univ., written by P. Aarne } \\
\text { Vesilind, directed by Jody McAuliff, } 35 \text { min }\end{array}$ \\
\hline "Engineering Disasters" & $\begin{array}{l}\text { From the leaning tower of Pisa to Soyuz } 11 \text {, here are the } \\
\text { fascinating - and sometimes tragic - tales of engineering gone } \\
\text { wrong 〈www.aande.com }\rangle\end{array}$ \\
\hline
\end{tabular}

At the New York Coliseum in 1955 (McKaig 1962; Kaminetzky 1991), about $929 \mathrm{~m}^{2}(10,000 \mathrm{sq} \mathrm{ft})$ of main exhibition hall collapsed during construction, killing one worker and injuring 50 others. The forms were two-stories high, supported on 3.35 m long, $89 \mathrm{~mm}$ square $(11 \mathrm{ft} 4 \times 4)$ timbers linked together by a cross beam at midheight. The crossbeams did not provide bracing against lateral instability. Buggies were used to transport the concrete for the slab being poured, and eight buggies were on the formwork at the time of collapse. According to the district attorney's office, the cause of failure was "inadequate provisions in the formwork to resist lateral forces" [McKaig (1962), p. 16]. Without proper bracing, the structure became unstable under the dynamic loading of the buggies. Formwork designs that had been safe before the use of buggies proved unsafe under the heavier loads. McKaig (1962) also discusses 14 other formwork failures.

\section{Sources for Case Materials}

There are many sources for case studies. These include books, technical papers, and magazine articles, videos, Web sites, prepared Microsoft PowerPoint presentations, and television programs.

\section{Books}

Three excellent texts are Feld and Carper (1997), Kaminetzsky (1991), and Levy and Salvadori (1992). McKaig (1962) is also good. Ross (1984) contains cases reprinted from Engineering News Record, a weekly publication covering the construction industry that often contains examples of recent failures. Shepherd and Frost (1995) contains short summaries of a wide variety of cases. Two excellent recent sources of case studies are the proceedings of the 1st and 2nd ASCE congresses on forensic engineering (Rens 1997; Rens et al. 2000 c).

Some books, such as Levy and Salvadori (1992) and Petroski (1985), do an excellent job of explaining fundamental structural behavior without relying on complex theories or mathematics and are particularly appropriate for lower-division undergraduate students.

\section{Papers and Articles}

Engineering News Record, addressed briefly above, is a good source of news on recent cases. Another excellent source is the quarterly Journal of Performance of Constructed Facilities, published by ASCE. Other ASCE journals, such as the Journal of Structural Engineering and Journal of Professional Issues in Engineering Education and Practice, often feature useful case studies. A useful bibliography on failures was assembled in a paper by Nicastro (1996), as noted earlier.

\section{Video}

An excellent video illustrating case studies is "When Engineering Fails," written and presented by Henry Petroski. This videotape 
Table 4. Available Case Study Web Sites (Based on Delatte 2000)

\begin{tabular}{|c|c|}
\hline Topic or case & URL \\
\hline \multirow[t]{3}{*}{ UAB REU site case studies } & 〈http://www.eng.uab.edu/cee/REU_NSF99/rachelwork.htm〉 \\
\hline & 〈http://www.eng.uab.edu/cee/REU_NSF99/reu_nsf00/carlos>ebpage2.htm〉 \\
\hline & 〈http://www.eng.uab.edu/cee/REU_NSF99/reu2001/King.htm〉 \\
\hline \multirow[t]{2}{*}{ Assorted case studies } & $\langle$ http://carbon.cudenver.edu/ $\sim$ mclark $/\rangle$ \\
\hline & $\langle$ http://www.eos.uoguelph.ca/webfiles/james/FamousEngrgDisasters.htm $\rangle$ \\
\hline Investigations-SGH & $\langle$ http://www.sgh.com/investig.htm $\rangle$ \\
\hline \multirow[t]{5}{*}{ Tacoma Narrows } & $\langle\mathrm{http}$ //www.bergen.org/AAST/Projects/Timeline/Transportation20/tacoma/index.htm $\rangle$ \\
\hline & $\langle$ http://www.nwwf.com/wa003a.htm $\rangle$ \\
\hline & $\langle$ http://www.math.uconn.edu/ kmoore/tacoma.html $\rangle$ \\
\hline & $\langle$ http://www.stkate.edu/physics/phys111/curric/tacomabr.html $\rangle$ \\
\hline & $\langle$ http://www.me.utexas.due/ uer/papers/paper_jk.html $\rangle$ \\
\hline \multirow[t]{2}{*}{ Hyatt Regency } & $\langle$ http://www.uoguelph.ca/ ajenney/webpage.htm $\rangle$ \\
\hline & $\langle\mathrm{http}: / /$ lowery.tamu.edu/ethics/ethics/hyatt/hyatt1.htm $\rangle$ \\
\hline
\end{tabular}

very closely parallels the book "To Engineer is Human" (Petroski 1985) and provides dramatic footage of the Hyatt Regency walkway collapse, the Tacoma Narrows Bridge collapse, and other cases.

Another quality video that illustrates a specific failure analysis case study, professional ethics, and rehabilitation can be found at the Arts and Entertainment Channel (A\&E)'s investigative reports. This story, titled "Fatal Flaw_A Skyscrapers' Nightmare," describes when the engineer of record William LeMessurier went public about the inadequate design of the Citibank skyscraper in New York City. A paper chronicling the events can be found in Morgenstern (1997). The video has several clips of LeMessurier documenting his trouble with peace of mind when he discovered, after the skyscraper was already constructed and inhabited by office staff, that the lateral bracing was inadequately designed. The video illustrates how local officials worked with emergency response individuals to develop a plan to evacuate a several-block region should winds reach a critical magnitude. In the end, working in the evenings, a major rehabilitation was accomplished and failure was avoided without public knowledge (and ensuing panic). LeMessurier presented a talk on this issue at the $1 \mathrm{ASCE}$ forensic congress (Rens 1997). Table 3 describes these and several other educational videos dealing with engineering failures, natural disasters, and ethics.

\section{Internet}

Several Web sites also provide case studies, or images to go with case studies, as shown in Table 4. Rachel Martin's Web site, the first listed, provides links to many of the others. The UCD also has a Web site with cases and is continuing to collect more (Rens et al. 2000a, b).

\section{Presentations}

The TCFE's Committee on the Dissemination of Failure Information has prepared a set of presentations, "Failure Vignettes," which are targeted at architects but may also be of value to engineering educators (Zickel 2000).

Table 5. Case Study Television Channels and Programs

\begin{tabular}{|c|c|c|}
\hline Channel & Web site & Typical program title and description \\
\hline The Discovery Channel & $\langle$ www.discoverychannel.com $\rangle$ & $\begin{array}{l}\text { "New Detectives: Case Studies in Forensic Science"-Some of } \\
\text { the best clues come from the least likely places. Baffling crimes } \\
\text { have been solved and criminals betrayed through evidence } \\
\text { provided by insects, beer bottles, and other seemingly } \\
\text { meaningless objects }\end{array}$ \\
\hline The Learning Channel & $\langle w w w . t l c . c o m\rangle$ & $\begin{array}{l}\text { "Without Warning: Bridge Collapse"-In 1995, the old Songsu } \\
\text { Bridge in Seoul, Korea, collapsed. News reports show the gaping } \\
\text { hole in the popular commuter bridge and the death and } \\
\text { destruction below }\end{array}$ \\
\hline The Arts and Entertainment (A\&E) Channel & $\langle w w w . a a n d e . c o m\rangle$ & $\begin{array}{l}\text { "Greatest Blunders of the 20th Century"-The 20th century } \\
\text { witnessed a long parade of stunning achievements, from the } \\
\text { popularization of the automobile to the landing on the moon. But } \\
\text { there is a flipside to these stories, for the path to progress has not } \\
\text { always been smooth }\end{array}$ \\
\hline
\end{tabular}




\section{Television}

Several excellent, educational regular television programs deal with forensic science. Some of these programs are centered on the subject of pathology, but many of the procedures are well suited to engineering failure analysis. In particular, the gathering of evidence, interviewing witnesses, photography, document preservation, and interpretation of results are common topics. A look at the television listings via the Internet revealed the programs listed in Table 5. In addition, many of the videotapes shown in Table 3 are occasionally broadcast.

\section{Summary, Recommendations, and Conclusions}

The formation of the TCFE and its representative committees in the early 1980s marked an important benchmark for failure analysis and education. Since that time, numerous articles and a wealth of other sources have been published on the subject. The cases and sources identified in this paper represent a starting point in the development of case studies in civil engineering education. This paper also reflects 20 years worth of evolution of failure analysis education. It is hoped that the interest will grow exponentially over the next 20 -year period as well.

\section{Acknowledgments}

Rachel Martin and Suzanne King gathered much of the background material for this paper; Martin prepared Figs. 1-4. Their work was supported by the National Science Foundation Research Experiences for Undergraduates site at the University of Alabama at Birmingham under Grant No. EEC-9820484. Professor Oswald Rendon-Herrero of Mississippi State University provided copies of course syllabi for a number of past offerings of his CE 4003 forensic engineering course.

\section{References}

Amini, F., and Khalilian, A. (1997). "Old post office foundation failure investigation." J. Perform. Constr. Facil., 11(1), 13-17.

Baer, R. J. (1996). "Guest editorial (Are civil engineering graduates adequately informed on failure? A practitioner's view)." J. Perform. Constr. Facil., 10(2), 46.

Bell, G. R., and Liepins, A. A. (1997). "More misapplications of the finite element method." Forensic engineering, K. L. Rens, ed., ASCE, New York, 258-267.

Bosela, P. A. (1993). "Failure of engineered facilities: Academia responds to the challenge." J. Perform. Constr. Facil., 7(2), 140-144.

Carper, (2000). "Lessons from failures: Case studies as an integral component of the civil engineering curriculum." Civil and structural engineering education in the 21 st century, Southampton, U.K.

Day, R. W. (1992). "Damage to two apartment buildings due to moisture variation of expansive soil." J. Perform. Constr. Facil., 6(3), 169176.

Day, R. W. (1993). "Performance of utility-trench shoring: Case study." J. Perform. Constr. Facil., 7(1), 20-26.

Day, R. W. (1994a). "Performance of fill that contains organic matter." $J$. Perform. Constr. Facil., 8(4), 264-273.

Day, R. W. (1994b). "Performance of slab-on-grade foundations on expansive soil." J. Perform. Constr. Facil., 8(2), 128-138.

Day, R. W. (1995). "Case study of the settlement of gravelly sand backfill.” J. Perform. Constr. Facil., 9(3), 184-193.

Delatte, Jr., N. J. (1997). “Integrating failure case studies and engineering ethics in fundamental engineering mechanics courses." J. Prof. Issues
Eng. Educ. Pract., 123(3), 111-116.

Delatte, N. J. (2000). "Using failure case studies in civil engineering education." Forensic engineering, K. L. Rens, O. Rendon-Herrero, and P. A. Bosela, eds., ASCE, Reston, Va., 430-440.

Diaz, C. F., Hadipriono, F. C., and Pasternack, S. (1994). "Failures of residential building basements in Ohio." J. Perform. Constr. Facil., 8(1), 65-80.

Dutson, A. J., Todd, R. H., Magleby, S. P., and Sorensen, C. D. (1997). "A Review of Literature on Teaching Engineering Design Through Project-Oriented Capstone Courses," J. Eng. Educ., 86(1).

Feld, J., and Carper, K. (1997). Construction failure, 2nd Ed., Wiley, New York.

Gillum, J. D. (2000). "The engineer of record and design responsibility." J. Perform. Constr. Facil., 14(2), 67-70.

Gnaedinger, J. P. (1987). "Open hearth slag-A problem waiting to happen.” J. Perform. Constr. Facil., 1(2), 78-83.

Goldstein, E. W. (1999). Timber construction for architects and builders, McGraw-Hill, New York.

Handy, R. L. (1995). The day the house fell, ASCE, New York.

Jennings, A., and Mackinnon, P. (2000). "Case for undergraduate study of disasters." J. Perform. Constr. Facil., 14(1), 38-41.

Kaminetzky, D. (1991). Design and construction failures: Lessons from forensic investigations, McGraw-Hill, New York.

LaCome, M. L., Blankespoor, A., and Rens, K. L. (2000). "Concrete maturity: A valid nondestructive evaluation and forensic tool." Proc., 2nd Forensic Congress, ASCE, Reston, Va. 172-182.

Leonards, G. A., Frost, J. D., and Bray, J. D. (1994). "Collapse of geogrid-reinforced retaining structure." J. Perform. Constr. Facil., 8(4), 274-292.

Levy, M., and Salvadori, M. (1992). Why buildings fall down: How structures fail, Norton, New York.

Lew, H., Fattel, S., Shaver, J., Reinhold, T., and Hunt, B. (1979). Investigation of construction failure of reinforced concrete cooling tower at Willow Island, W.V., U.S. Dept. of Labor, OSHA/National Bureau of Standards, Washington, D.C.

Lew, H. S., et al. (1982). "Investigation of construction failure of Harbour Cay Condominium in Cocoa Beach, Florida." Rep. S/N 003-0030245-8, U.S. Dept. of Commerce, National Bureau of Standards, Washington, D.C.

Lin, H.-M., and Hadipriono, F. C. (1990). "Problems in deep foundation construction in Taiwan." J. Perform. Constr. Facil., 4(4), 259-270.

Luth, G. P. (2000). "Chronology and context of the Hyatt Regency collapse." J. Perform. Constr. Facil., 14(2), 51-61.

Martin, R., and Delatte, N. (2000). "Another look at L'Ambiance Plaza collapse." J. Perform. Constr. Facil., 14(4), 160-165.

Martin, R., and Delatte, N. (2001). "Another look at Hartford Civic Center Coliseum collapse.” J. Perform. Constr. Facil., 15(1), 31-36.

McKaig, T. (1962). Building failures: Case studies in construction and design, McGraw-Hill, New York.

Meehan, R. L., and Karp, L. B. (1994). "California housing damage related to expansive soils." J. Perform. Constr. Facil., 8(2), 139-157.

Moncarz, P. D., and Taylor, R. K. (2000). "Engineering process failureHyatt Walkway collapse." J. Perform. Constr. Facil. 14(2), 46-50.

Morgenstern, J. (1997). "The fifty-nine story crisis." J. Prof. Issues Eng. Educ. Pract., 123(1), 23-29.

Nicastro, D. H. (1996). “Annotated bibliography of forensic engineering." J. Perform. Constr. Facil., 10(1), 2-4.

Padmanabhan, G., and Katti, D. (2002). "Using community-based projects in civil engineering capstone courses." J. Prof. Issues Eng. Educ. Pract., 128(1), 12-18.

Petroski, H. (1985). To engineer is human, St. Martins, New York.

Pfatteicher, S. K. A. (2000). "The Hyatt horror: Failure and responsibility in American engineering." J. Perform. Constr. Facil., 14(2), 62-66.

Pietroforte, R. (1998). "Civil engineering education through case studies of failures." J. Perform. Constr. Facil., 12(2), 51-55.

Puri, S. P. S. (1997). "Computer misuse-Are we dealing with a time bomb? Who is to blame and what are we doing about it?" Forensic engineering, K. L. Rens, ed., ASCE, New York, 285-336.

Puri, S. P. S. (1998). "Discussion of 'Integrating Failure case studies and 
engineering ethics in fundamental engineering mechanics courses,' by N. J. Delatte." J. Prof. Issues Eng. Educ. Pract., 124(4), 123-124.

Raghu, D., and Hsieh, H.-N. (1989). "Performance of some structures constructed on chromium ore fills." J. Perform. Constr. Facil., 3(2), $113-120$.

Rendon-Herrero, O. (1993a). "Including failure case studies in civil engineering courses." J. Perform. Constr. Facil., 7(3), 181-185.

Rendon-Herrero, O. (1993b). "Too many failures: What can education do?" J. Perform. Constr. Facil., 7(2), 133-139.

Rendon-Herrero, O. (1998). "Experience teaching civil engineering failures 1973-1997." Structural Engineering World Congress, San Francisco.

Rens, K. L., ed. (1997). Forensic engineering, ASCE, New York.

Rens, K. L., and Knott, A. W. (1997). "Teaching experiences: A graduate course in condition assessment and forensic engineering." Forensic engineering, K. L. Rens, ed., ASCE, New York, 178-185.

Rens, K. L., Clark, M. J., and Knott, A. W. (2000a). "A failure analysis case study information disseminator." J. Perform. Constr. Facil., 4(3), $127-31$.

Rens, K. L., Clark, M. J., and Knott, A. W. (2000b). "Development of an Internet failure information disseminator for professors." Forensic Engineering, K. L. Rens, O. Rendon-Herrero, and P. A. Bosela, eds., ASCE, Reston, Va.

Rens, K. L., Rendon-Herrero, O., and Bosela, P. A. eds. (2000c). Forensic Engineering, ASCE, Reston, Va.

Rens, K. L., Rendon-Herrero, O., and Clark, M. J. (2000d). "Failure of constructed facilities in the civil engineering curricula." J. Perform. Constr. Facil., 4(1), 27-37.
Rens, K. L., Royston, H. J., and Lacome, M. L. (2000e). “Temporary bracing during construction (fact or fiction): Case studies." Proc., Forensic Engineering: 2nd Congress, San Juan, Puerto Rico 652 661.

Richardson, D. N., Stephenson, R. W., and Molloy, D. (1987). "Soilshrinkage induced structural failure." J. Perform. Constr. Facil., 1(4), 219-228.

Roddis, W. M. K. (1993). “Structural failures and engineering ethics.” $J$. Struct. Eng., 119(5), 1539-1555.

Ross, S. (1984), Construction disasters: Design failures, causes, and prevention, McGraw-Hill, New York.

Shepherd, R., and Frost, J. D. (1995). Failures in civil engineering: Structural, foundation, and geoenvironmental case studies, ASCE, New York.

Thornton, C. H., and DeScenza, R. P. (1997). "Construction collapse of precast concrete framing at Pittsburgh's Midfield Terminal," Forensic engineering: K. L. Rens, ed., ASCE, New York, 85-93.

Whitlock, A. R., and Mossa, S. S. (1996). "Foundation design considerations for construction on marshlands." J. Perform. Constr. Facil., 10(1), 15-22.

Shallow Foundations Committee of the Geotechnical Division. (1995). So your home is built on expansive soils, W. K. Wray, chairman, ASCE, New York.

Zickel, L. L. (2000). "Failure vignettes for teachers." Proc., 2nd Forensic engineering, K. L. Rens, O. Rendon-Herrero, and P. A. Bosela, eds., ASCE, Reston, Va., 421-429. 